\title{
ANALISIS KESALAHAN PEMECAHAN MASALAH KASUS EQUILIBRIUM, BREAK EVENT POINT DAN PROGRAM LINIER
}

\author{
Herlina \\ Jurusan Teknik Informatika Universitas Bunda Mulia Jakarta Utara \\ jc.herlina@gmail.com
}

\begin{abstract}
ABSTRAK
Tujuan dalam penelitian ini adalah mengetahui kesalahan-kesalahan mahasiswa/i dalam memecahkan kasus equilibrium, break event point dan program linear, mengetahui penyebab mahasiswa/i melakukan kesalahan dalam memecahkan kasus equilibrium, break event point dan program linear, mengetahui cara-cara mengatasi masalah mahasiswa/i dalam memecahkan kasus equilibrium, break event point dan program linear. Hasil penelitian ini adalah kesalahan-kesalahan yang dilakukan mahasiswa pada kasus equlibrium, break event point dan program linier secara umum adalah 1) kesalahan menerjemahkan bahasa, kesalahan pada saat menentukan apa yang diketahui dan apa yang tidak diketahui; 2) kesalahan konsep dalam memberikan tanggapan konsep perumusan atau dalil matematika; 3) kesalahan strategi penyelesaian masalah dalam operasi hitung, pindah ruas, menentukan kesimpulan. Penyebab kesalahan mahasiswa dalam menyelesaikan kasus equlibrium, break event point dan program linier secara umum adalah 1) penyebab kesalahan pada saat penerjemahan yaitu mahasiswa masih kurang paham apa yang ditanyakan, 2) penyebab kesalahan pada saat tanggapan/konsep yaitu mahasiswa masih kurang paham apa yang menjadi tujuan soal sehingga mahasiswa masih bingung menentukan langkah apa yang akan dilakukan untuk menyelesaikan masalah tersebut. 3) penyebab kesalahan pada saat strategi yaitu mahasiswa kurang teliti dalam melakukan oprasi hitung. Cara mengatasi masalah mahasiswa/i dalam memecahkan kasus equilibrium, break event point dan program linear adalah 1) dosen memberikan latihan soal berupa kasus dan membahas penyelesaian secara bersama-sama serta memberitahukan titik-titik rawan kesalahan yang banyak dilakukan mahasiswa, 2) dalam ujian tertutup, untuk mengurangi kesalahan penulisan rumus-rumus maka rumus-rumus perlu dicantumkan.
\end{abstract}

Kata kunci: Kesalahan-kesalahan pemecahan masalah, equlibrium, break event point, program linier

\begin{abstract}
The purpose of this research was to determine the errors students in solving the case of equilibrium, break event point and linear programming, determine the cause of the students make mistakes in solving the case of equilibrium, break event point and linear programming, to know the ways to overcome the problem of students in solving the case of equilibrium, break event point and linear programming. The results of this study are the mistakes done by the students in the case of equlibrium, break event point and linear programming in general is 1) errors translate, errors when determining what is known and what is unknown; 2) mistake concepts for response formulation concepts or mathematical proposition; 3) error problem-solving strategies in arithmetic operations, moving segments, determine conclusion. Causes of errors students in completing the case equlibrium, break event point and linear programming in general are 1) the cause of the error when translating that students still do not understand what is being asked, 2) the cause of the error at the time of response/ concepts that the students still do not understand what the destination matter so that the student is still deciding what steps will be taken to resolve the problem. 3) the cause of the error at the time the strategy is a student less scrupulous in oprasi count. How to overcome the problem of students in solving the case of equilibrium, break event point and linear programming are 1) the lecturer gives exercises in the form of case and discuss solutions together and telling the
\end{abstract}


vulnerable points of error that a lot of students, 2) in a close examination, to reduce the error of writing formulas, the formulas to be given.

Keywords: errors troubleshooting, equlibrium, break event point, linear programming

\section{Latar Belakang}

Matematika ekonomi dan bisnis merupakan mata kuliah yang diajarkan di perguruan tinggi pada beberapa program studi. Syarat sebelum belajar matematika ekonomi dan bisnis adalah mahasiswa/i sudah menguasai konsep dasar aljabar matematika. Mata kuliah ini menuntut mahasiswa/i untuk dapat mengubah kasus ekonomi ke dalam bentuk-bentuk simbol matematika atau sebaliknya. Keberadaan mata kuliah ini supaya mahasiswa/i mampu mengaplikasikan matematika dalam perekonomian, tetapi juga sebagai sarana mendorong munculnya sikap positif mahasiswa/i terhadap matematika dengan memperlihatkan kebermaknaan matematika dalam kehidupan sehari-hari pada umumnya dan dalam bidang ekonomi pada khususnya. Berdasarkan data Layanan Akademik Universitas Bunda Mulia, nilai rata-rata ujian matematika ekonomi selama tiga tahun terakhir sebagai berikut:

Tabel 1. Nilai Rata-Rata Ujian Matematika Ekonomi Universitas Bunda Mulia

\begin{tabular}{ccc}
\hline $\mathbf{2 0 1 2} / \mathbf{2 0 1 3}$ & $\mathbf{2 0 1 3 / 2 0 1 4}$ & $\mathbf{2 0 1 4 / 2 0 1 5}$ \\
\hline 59,64 & 53,53 & 56,75 \\
\hline
\end{tabular}

Berdasarkan informasi tersebut, nilai rata-rata matematika ekonomi dan bisnis di Universitas Bunda Mulia tergolong cukup baik, nilai ini masih jauh dari harapan. Untuk itu diperlukan penelitian-penelitian yang membahas sebab-sebab nilai matematika ekonomi dan bisnis masih jauh dari harapan. Dalam penelitian ini akan menyelidiki bagaimana kesalahan-kesalahan mahasiswa/i dalam memecahkan kasus equilibrium, break event point dan program linier. Kasus-kasus tersebut merupakan kasus satu rumpun pada matematika yaitu penerapan persamaan dan pertidaksamaan pada kasus ekonomi.

Berdasarkan uraian hasil penelitian tersebut, apakah tipe-tipe kesalahan berlaku pada mahasiswa/i Universitas Bunda Mulia pada kasus equlibrium, break event point dan program linier. Berdasarkan hal tersebut, peneliti tertarik untuk mendeskripsikan kesalahan-kelasalahan yang dialami mahasiswa/i Universitas Bunda Mulia Semester I pada Program Studi Manajemen dalam memecahkan kasus equilibrium, break event point dan program linier pada mata kuliah matematika ekonomi dan bisnis.

\section{Dasar Teori}

Dalam bidang matematika, elemen-elemen penting belajar matematika adalah masalah yang dapat mengembangkan kemampuan peserta 
didik menyangkut berbagai hal teknik dan strategi pemecah masalah, pengetahuan, keterampilan dan pemahaman termuat dalam soal cerita. Suatu pertanyaan merupakan suatu masalah bagi peserta didik pada suatu masa, tetapi suatu masalah yang sama tidak akan menjadi masalah bagi perserta didik pada periode berikutnya setelah peserta didik mengetahui cara mengatasi penyelesaian tersebut.

Mark Joyner (2008:

menuliskan tentang metode pemecahan masalah yang diambil dari karya $\mathrm{G}$. Polya. How to solve it, edisi ke-2, Princeton Unersity Press, 1957, ISBN 0691-08097-6 menjelaskan empat langkah yang harus dilakukan dalam memecahkan masalah yaitu:

(1) Memahami masalah. Memahami masalah meliputi apa yang diketahui, apa yang tidak diketahui, membuat satu Gambaran atau menuliskan sesuai dengan kondisi.

(2) Merencanakan penyelesaian. Merencanakan penyelesaian meliputi: menemukan hubungan antara data dan masalah-masalah yang berkaitan, membuat rencana solusi,

(3) Menyelesaikan rencana penyelesaian. Menyelesaikan rencana penyelesaian meliputi: langkah-langkah yang digunakan, strategi penyelesaian.
(4) Evaluasi. Evaluasi meliputi: memeriksa solusi yang digunakan, membuat solusi.

\section{Metode}

Penelitian ini merupakan penelitian kualitatif dengan teknik deskriptif. Data berupa dokumen hasil ujian tengah semester pada kasus equilibrium, break event point dan program linier dan Koesioner tentang terjadinya kesalahan dalam pemecahan masalah mahasiswa/i pada kasus equilibrium, break event point dan program linier berdasarkan lembar jawab mahasiswa/i hasil Ujian Tengah Semester.

Pengambilan subyek penelitian dilakukan secara purposive mahasiswa/i Prodi Manajemen semester 1 periode Ganjil 2015-2016 yang telah mengikuti Ujian Tengah Semester pada mata kuliah matematika ekonomi dan bisnis.

Teknik analisa data menggunakan metode konten analisis. Konten-konten yang dianalisis dalam dokumen berkas ujian tengah semester menggunakan teori Polya sebagai berikut:

Tabel 2. Analisis kesalahan mahasiswa/i pada kasus equilibrium

\begin{tabular}{lll}
\hline No & Teory Polya & Analisis Kesalahan \\
\hline $\mathbf{1}$ & $\begin{array}{l}\text { Memahami } \\
\text { Masalah }\end{array}$ & $\begin{array}{l}\text { Menuliskan model } \\
\text { matematika dari suatu } \\
\text { kasus }\end{array}$ \\
$\mathbf{2}$ & $\begin{array}{l}\text { Merencanakan } \\
\text { Penyelesaian }\end{array}$ & $\begin{array}{l}\text { Menentukan fungsi } \\
\text { permintaan atau } \\
\text { penawaran }\end{array}$ \\
$\mathbf{3}$ & $\begin{array}{l}\text { Menyelesaikan } \\
\text { Rencana }\end{array}$ & $\begin{array}{l}\text { Strategi penyelesaian } \\
\text { (perumusan, langkah- } \\
\text { Penyelesaian }\end{array}$ \\
$\mathbf{4}$ & $\begin{array}{l}\text { Memeriksa } \\
\text { Kembali }\end{array}$ & $\begin{array}{l}\text { Kesimpulan } \\
\text { penyelesaian } \\
\text { pemecahan masalah }\end{array}$ \\
\hline
\end{tabular}


Penentuan titik equlibrium

Tabel 3. Analisis kesalahan mahasiswa/i pada kasus break event point dan program linier

\begin{tabular}{|c|c|c|}
\hline No & Teory Polya & Analisis Kesalahan \\
\hline 1 & $\begin{array}{l}\text { Memahami } \\
\text { Masalah }\end{array}$ & $\begin{array}{l}\text { Menuliskan model } \\
\text { matematika dari suatu } \\
\text { kasus }\end{array}$ \\
\hline 2 & $\begin{array}{l}\text { Merencanakan } \\
\text { Penyelesaian }\end{array}$ & $\begin{array}{l}\text { Menentukan fungsi } \\
\text { biaya dan fungsi } \\
\text { penerimaan }\end{array}$ \\
\hline 3 & $\begin{array}{l}\text { Menyelesaikan } \\
\text { Rencana } \\
\text { Penyelesaian }\end{array}$ & $\begin{array}{l}\text { Strategi penyelesaian } \\
\text { (perumusan, langkah- } \\
\text { langkah) }\end{array}$ \\
\hline 4 & $\begin{array}{l}\text { Memeriksa } \\
\text { Kembali }\end{array}$ & $\begin{array}{l}\text { Kesimpulan } \\
\text { penyelesaian } \\
\text { pemecahan masalah } \\
\text { Penentuan break event } \\
\text { point }\end{array}$ \\
\hline
\end{tabular}

Tabel 4. Analisis kesalahan mahasiswa/i pada kasus program linier

\begin{tabular}{|c|c|c|}
\hline No & Teory Polya & Analisis Kesalahan \\
\hline 1 & Memahami & Menentukan fungsi \\
\hline 2 & Merencanakan & Menetukan faktor \\
\hline 3 & $\begin{array}{l}\text { Menyelesaikan } \\
\text { Rencana } \\
\text { Penyelesaian }\end{array}$ & $\begin{array}{l}\text { Strategi penyelesaian } \\
\text {-Menentukan titik } \\
\text { ekstrim dan batas- } \\
\text { batasnya pada grafik }\end{array}$ \\
\hline 4 & $\begin{array}{l}\text { Memeriksa } \\
\text { Kembali }\end{array}$ & $\begin{array}{l}\text { Kesimpulan } \\
\text { penyelesaian } \\
\text { pemecahan masalah }\end{array}$ \\
\hline
\end{tabular}

Data mengenai penyebab kesalahan yang dilakukan mahasiswa/i dalam menyelesaikan pemecahan masalah pada kasus-kasus tersebut, dilakukan dengan penyebaran koesioner.

\section{Hasil dan Pembahasan}

Hasil

Subyek penelitian ini 223 Mahasiswa/i/i. Berikut penjabaran hasil Ujian Tengah Semester Ganjil 2015-2016 pada mata kuliah Matematika Ekonomi \&
Bisnis. Analisis kesalahan memiliki nilai 0 dan 1. Nilai nol (0) mengartikan bahwa mahasiswa/i tidak tahu apa yang dikerjakan atau tidak memahami bagaimana memecahkan masalah kasus equlibrium. Nilai satu (1) menunjukan bahwa bahwa mahasiswa/i mengetahui apa yang sedang di kerjakan atau memiliki arah atau sudah memahami maksud soal.

Kasus Equlibrium,

Harga suatu produk Rp3.000,- maka permintaan akan produk tersebut 300 unit, tetapi saat harga meningkat menjadi Rp5.000,- maka permintaan akan produk tersebut menurun menjadi 100 unit. Jika harga suatu produk Rpl.000,- maka jumlah yang ditawarkan produsen sebanyak 50 unit bila produsen menaikan harga menjadi Rp2.000,- maka jumlah produk yang ditawarkan produsen sebanyak 200 unit.

Berdasarkan ilustrasi diatas, anda diminta untuk:

a. Tuliskan fungsi permintaan dan penawaran!

b. Hitung harga dan jumlah keseimbangan!

Jawab:

Memahami Masalah : Menentukan Model Matematika

Fungsi permintaan $\mathrm{P} 1=3000 \quad \mathrm{P} 2=$ 5000

$$
\begin{gathered}
\mathrm{Q} 1=300 \quad \mathrm{Q} 2=100 \\
\frac{P-P_{1}}{P_{2}-P_{1}}=\frac{Q-Q_{1}}{Q_{2}-Q_{1}}
\end{gathered}
$$




$$
\begin{aligned}
& \frac{P-3000}{5000-3000}=\frac{Q-300}{100-300} \\
& \frac{P-3000}{2000}=\frac{Q-300}{-200} \\
& -200(\mathrm{P}-3000)=2000(\mathrm{Q}-300) \\
& -200 \mathrm{P}+600.000 \quad=2000 \mathrm{Q}-600.000 \\
& -200 \mathrm{P}+1.200 .000=2000 \mathrm{Q} \\
& -0,1 \mathrm{P}+600=\mathrm{Q}
\end{aligned}
$$

Atau

$$
\begin{aligned}
-200 \mathrm{P}+600.0000 & =2000 \mathrm{Q}-600.000 \\
-200 \mathrm{P} & =2000 \mathrm{Q}-1.200 .000 \\
\mathrm{P} & =-10 \mathrm{Q}+6000
\end{aligned}
$$

Fungsi penawaran $\mathrm{P} 1=1000 \quad \mathrm{P} 2=2000$

$\mathrm{Q} 1=50 \quad \mathrm{Q} 2=200$

$\frac{P-1000}{2000-1000}=\frac{Q-50}{200-50}$

$\frac{P-1000}{1000}=\frac{Q-50}{150}$

$150(\mathrm{P}-1000)=1000(\mathrm{Q}-50)$

$150 \mathrm{P}-150.000=1000 \mathrm{Q}-50.000$

$150 \mathrm{P}-100.000=1000 \mathrm{Q}$

$$
0,15 \mathrm{P}-100=\mathrm{Q}
$$

Atau

$150(\mathrm{P}-1000)=1000(\mathrm{Q}-50)$

$150 \mathrm{P}-150.000=1000 \mathrm{Q}-50.000$

$150 \mathrm{P}=1000 \mathrm{Q}+100.000$

$P=\frac{100}{15} Q+\frac{10.000}{15}$

Fungsi penawaran P1 $=1000 \quad \mathrm{P} 2=2000$

$\mathrm{Q} 1=50 \quad \mathrm{Q} 2=200$

$$
\frac{P-1000}{2000-1000}=\frac{Q-50}{200-50}
$$

$$
\frac{P-1000}{1000}=\frac{Q-50}{150}
$$$$
150(\mathrm{P}-1000)=1000(\mathrm{Q}-50)
$$$$
150 \mathrm{P}-150.000=1000 \mathrm{Q}-50.000
$$$$
150 \mathrm{P}-100.000=1000 \mathrm{Q}
$$

$$
0,15 \mathrm{P}-100=\mathrm{Q}
$$

Atau

$150(\mathrm{P}-1000)=1000(\mathrm{Q}-50)$

$150 \mathrm{P}-150.000=1000 \mathrm{Q}-50.000$

$150 \mathrm{P}=1000 \mathrm{Q}+100.000$

$P=\frac{100}{15} Q+\frac{10.000}{15}$

Menyelesaikan Rencana Penyesaian:

Strategi Penyelesaian

Keseimbangan

$\mathrm{Qd}=-0,1 \mathrm{P}+600$

Qs $=0,15 \mathrm{P}-100$

Syarat Keseimbangan

$\mathrm{Qd}=\mathrm{Qs}$

$-0,1 \mathrm{P}+600=0,15 \mathrm{P}-100$

$-0,25 \mathrm{P}=-700$

$\mathrm{P}=2.800$ Maka $\mathrm{Q}=320$

Maka E (320 unit, Rp2.800)

Atau

$P d=-10 Q+6000 \&$

$$
P S=\frac{100}{15} Q+\frac{10.000}{15}
$$

Syarat keseimbangan

$\mathrm{Pd}=\mathrm{Ps}$

$$
\begin{aligned}
-10 \mathrm{Q}+6000 & =100 / 15 \mathrm{Q}+10.000 / 15 \\
-250 / 15 \mathrm{Q} & =10.000 / 15-6000 \\
-250 / 15 \mathrm{Q} & =-80.000 / 15 \\
\mathrm{Q} & =320 \text { Maka } \mathrm{P}=2.800
\end{aligned}
$$

Maka E (320 unit , Rp2.800)

Analisis kesalahan-kesalahan meliputi, penerjemahan bahasa, perumusan dan perhitungan. Jumlah mahasiswa yang dapat menyelesaikan kasus equlibrium secara benar $100 \%$ adalah 23 Mahasiswa/i atau 10,31\% dari 223 Mahasiswa/i. Berikut adalah persentase kesalahan yang dilakukan oleh mahasiswa pada setiap langkah. 
Tabel 5. Persentase Jumlah Mahasiswa/i Pada Setiap Langkah-Langkah Kasus Equlibrium

\begin{tabular}{lcccc}
\hline & $\begin{array}{c}\text { Menuliskan } \\
\text { model } \\
\text { matematika }\end{array}$ & $\begin{array}{c}\text { Menentukan } \\
\text { fungsi } \\
\text { permintaan atau } \\
\text { penawaran }\end{array}$ & $\begin{array}{c}\text { Strategi } \\
\text { penyelesaian } \\
\text { (Perumusan, } \\
\text { langkah-langkah) }\end{array}$ & $\begin{array}{c}\text { Kesimpulan } \\
\text { penyelesaian } \\
\text { pemecahan masalah } \\
\text { (Titik Equlibrium) }\end{array}$ \\
\hline $\begin{array}{l}\text { Kesalahan- } \\
\text { Kesalahan } \\
\text { Konsep }\end{array}$ & $43,95 \%$ & $34,08 \%$ & $34,08 \%$ & $8,97 \%$ \\
\hline
\end{tabular}

Kasus Break Event Point,

Tuan Andre membuka warung Bakso di sekitar kampus UBM. Setiap bulan Tuan Andre mengeluarkan uang sebesar Rp3.500.000,-. Untuk menghasilkan satu porsi Bakso ia mengeluarkan uang sebesar Rp5.500,- dan menjual Baksonya dengan harga Rp7.500,-. Berapa porsikah Tuan Andre menjual baksonya dalam kondisi Break Event Poin?

Jawab:

$\underline{\text { Memahami Masalah: Menuliskan model }}$ matematika

Diketahui :

Biaya tetap $(\mathrm{FC}) \quad=\mathrm{Rp} 3.500 .000,-$

Biaya per porsi $(\mathrm{V}) \quad=\mathrm{Rp} 5.500,-$

Harga jual per porsi $(\mathrm{P})=\mathrm{Rp} 7.500$,-

Merencanakan Penyelesaian:

Menentukan fungsi biaya total dan fungsi penerimaan total
Biaya Total $(\mathrm{TC})=\mathrm{FC}+\mathrm{VQ}=3.500 .000$

$+5.500 \mathrm{Q}$

Penerimaan Total $(\mathrm{TR})=\mathrm{PQ}=7.500 \mathrm{Q}$

Menyelesaikan Rencana Penyelesaian : $\underline{\text { Strategi penyelesaian (perumusan, }}$ perhitungan, langkah-langkah)

$\mathrm{Q}$ pada saat BEP

Syarat BEP adalah TR $=\mathrm{TC}$

$\mathrm{Q}=\mathrm{FC} /(\mathrm{P}-\mathrm{V})=3.500 .000 /(7.500-$ $5.500)=3.500 .000 / 2000=1.750$ unit

Analsis kesalahan-kesalahan meliputi, penerjemahan bahasa, perumusan dan perhitungan. Jumlah mahasiswa yang dapat menyelesaikan kasus break event point secara benar $100 \%$ adalah 23 Mahasiswa/i atau 10,31\% dari 223 Mahasiswa/i. Berikut adalah persentase kesalahan yang dilakukan oleh mahasiswa pada setiap langkah.

Tabel 6. Persentase Jumlah Mahasiswa/i Pada Setiap Langkah-Langkah Kasus Break Event Point

\begin{tabular}{lcccc}
\hline & $\begin{array}{c}\text { Menuliskan } \\
\text { Simbol } \\
\text { Matematika }\end{array}$ & $\begin{array}{c}\text { Menentukan } \\
\text { Fungsi Biaya } \\
\text { Total \& } \\
\text { Penerimaan } \\
\text { Total }\end{array}$ & $\begin{array}{c}\text { Strategi } \\
\text { Penyelesaian } \\
\text { (Perumusan \& } \\
\text { Langkah-langkah) }\end{array}$ & $\begin{array}{c}\text { Kesimpulan } \\
\text { Penyelesaian } \\
\text { Masalah ( BEP) }\end{array}$ \\
\hline $\begin{array}{l}\text { Kesalahan- } \\
\text { kesalahan } \\
\text { konsep }\end{array}$ & $39,91 \%$ & $34,53 \%$ & $30,04 \%$ & $10,31 \%$ \\
\hline
\end{tabular}

Analisis ... (Herlina) 
Kasus program linier,

Putri Ana adalah seorang model yang harus menjaga penampilan fisiknya. Ahli kesehatan menyarankan untuk mengkonsumsi paling banyak 1500 gram protein dan 1000 gram karbohidrat. Putri Ana menyiapkan paket menu makanan "green" dan "fress". Paket green mengandung 20 gram protein dan 10 gram karbohidrat dengan harga per paket Rp35.000,- sedangkan paket fress mengadung 30 gram protein dan 40 gram karbohodrat dengan harga per paket Rp40.000,-. Bantulah Putri Ana menghitung biaya minimal yang harus dikeluarkan untuk memenuhi kebutuhan hariannya dengan konsep program linier.

a. Ubahlah cerita diatas ke dalam bentuk pertidaksamaan!

b. Berapa biaya minimal yang harus di keluarkan Putri Ana, gunakan metode grafik!

Jawab:

Memahami Masalah : Menentukan fungsi tujuan \& fungsi Kendala

Misal Green : X1 \& Fress : X2

$\mathrm{C}=35.000 \times 1+40.000 \times 2$

$20 \times 1+30 \times 2 \leq 1500$

$10 \times 1+40 \times 2 \leq 1000$

$X 1 \geq 0 \& x 2 \geq 0$

Merencanakan Penyelesaikan :

Menentukan strategi penyelesaian

AdMathEdu | Vol.6 No.2 | Desember 2016

\begin{tabular}{|c|c|c|c|c|c|}
\hline \multicolumn{3}{|c|}{$20 \times 1+30 \times 2=1500$} & \multicolumn{3}{|c|}{$10 \times 1+40 \times 2=1000$} \\
\hline $\mathrm{x} 1$ & 0 & 75 & $\mathrm{x} 1$ & 0 & 100 \\
\hline $\mathrm{x} 2$ & 50 & 0 & $x 2$ & 25 & 0 \\
\hline
\end{tabular}

Menyelesaikan Rencana Penyelesaian :

$\underline{\text { Menentukan nilai ekstrem pada }}$

grafik/aljabar

$$
\begin{aligned}
& 20 \times 1+30 \times 2=1500|\times 1| 20 \times 1+80 \times 2=1500 \\
& 10 \times 1+40 \times 2=1000 \mid \times 2 \frac{\mid 20 \times 1+80 \times 2=2000}{-50 \times 2=-500}
\end{aligned}
$$

$x 2=10 \& x 1=60$

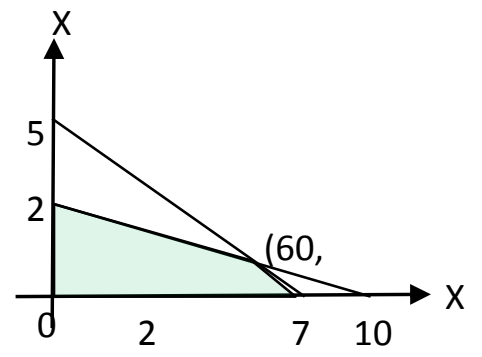

Memeriksa Kembali : Kesimpulan $\underline{\text { menyelesaikan masalah yaitu nilai }}$ optimum dari tujuan $\mathrm{C}=35.000 \times 1+40.000 \times 2$ $(75,0)>\mathrm{C}=3000.000$

$(60,10)>\mathrm{C}=2750.000$

$(0,25)>\mathrm{C}=875.000$

Jadi biaya minimum yang harus dikeluarkan adalah Rp875.000,-

Analisis kesalahan-kesalahan meliputi, penerjemahan bahasa dalam menentukan fungsi tujuan dan fungsi kendala, perumusan dan perhitungan. Jumlah mahasiswa yang dapat menyelesaikan kasus program linier secara benar $100 \%$ adalah 39

Analisis ... (Herlina) 
Mahasiswa/i atau $17,49 \%$ dari 223 kesalahan yang dilakukan oleh

Mahasiswa/i. Berikut adalah persentase mahasiswa pada setiap langkah.

Tabel 7. Kasus Program Linier

\begin{tabular}{cccccc}
\hline $\begin{array}{c}\text { Menentu } \\
\text { kan } \\
\text { Fungsi } \\
\text { Tujuan }\end{array}$ & $\begin{array}{c}\text { Menulisk } \\
\text { an } \\
\text { Faktor } \\
\text { Kendala }\end{array}$ & $\begin{array}{c}\text { Strategi Penyelesaian } \\
\text { (Perumusan, } \\
\text { Langkah-langkah, } \\
\text { Perhitungan }\end{array}$ & $\begin{array}{c}\text { Menentu } \\
\text { kan Titik } \\
\text { Ekstrim }\end{array}$ & $\begin{array}{c}\text { Kesimpulan } \\
\text { Penyelesaian }\end{array}$ \\
\hline $\begin{array}{c}\text { Kesalahan- } \\
\text { kelasahan Konsep }\end{array}$ & $20,63 \%$ & $36,77 \%$ & $27,80 \%$ & $25,56 \%$ & $17,49 \%$ \\
\hline
\end{tabular}

\section{Pembahasan}

Kesalahan-kesalahan mahasiswa/i dalam memecahkan kasus Equilibrium, Break Event Point dan Program linear.

\section{Kasus Equlibrium}

Pada kasus equlibrium, terdapat berbagai kesalahan mahasiswa/i dalam memecahkan masalah sebagai berikut:

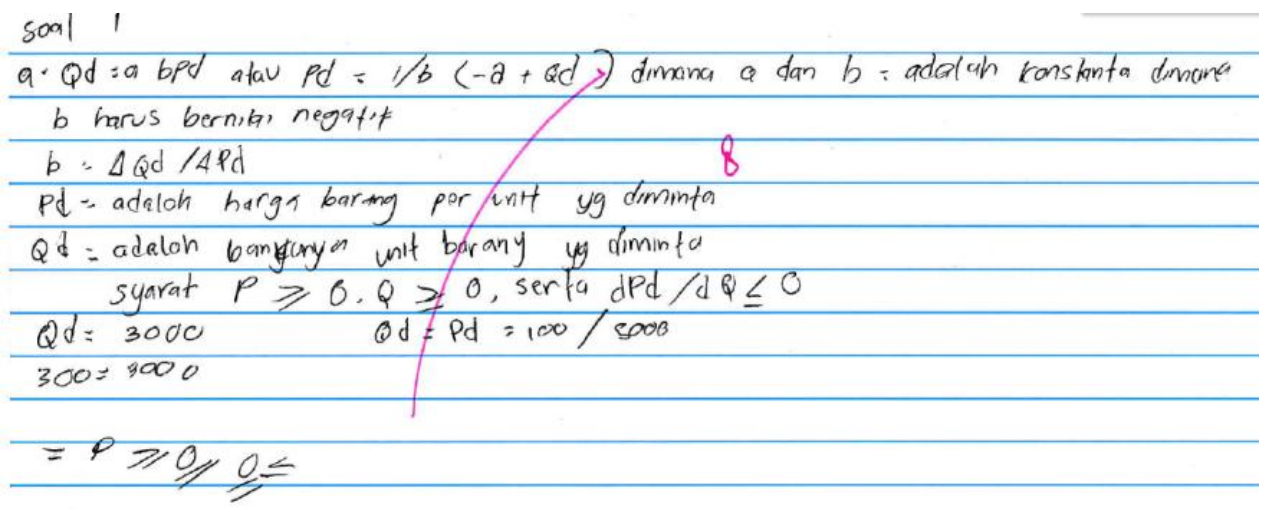

Gambar 1. Kesalahan Mahasiswa/i pada Kasus Equilibrium

Gambar 1 menunjukkan bahwa matematika sehingga dalam mahasiswa/i tidak memahami, tidak menyelesaikan pemecahan masalah tidak menguasi konsep equlibrium tidak dapat memiliki arah. menerjemahkan kasus ke dalam simbol

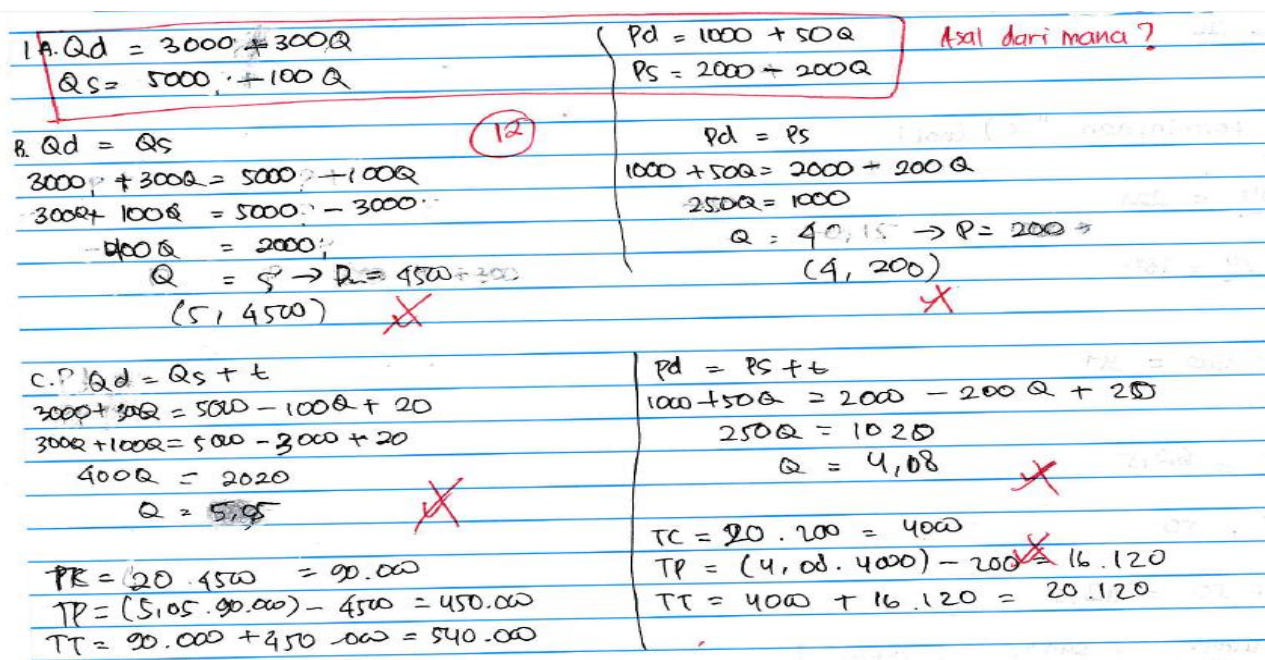

Gambar 2. Kesalahan Penerapkan Ke Dalam Rumus Matematika 
Gambar 2 menunjukkan bahwa mahasiswa/i sudah mampu menerjemahkan bahasa ke dalam simbol matematika. Namum kesalahan yang dilakukan mahasiswa/i adalah menerapkan apa yang diketahui ke dalam rumus matematika. Pembentukan fungsi tidak didasarkan dalil matematika sehingga fungsi ini tidak benar.

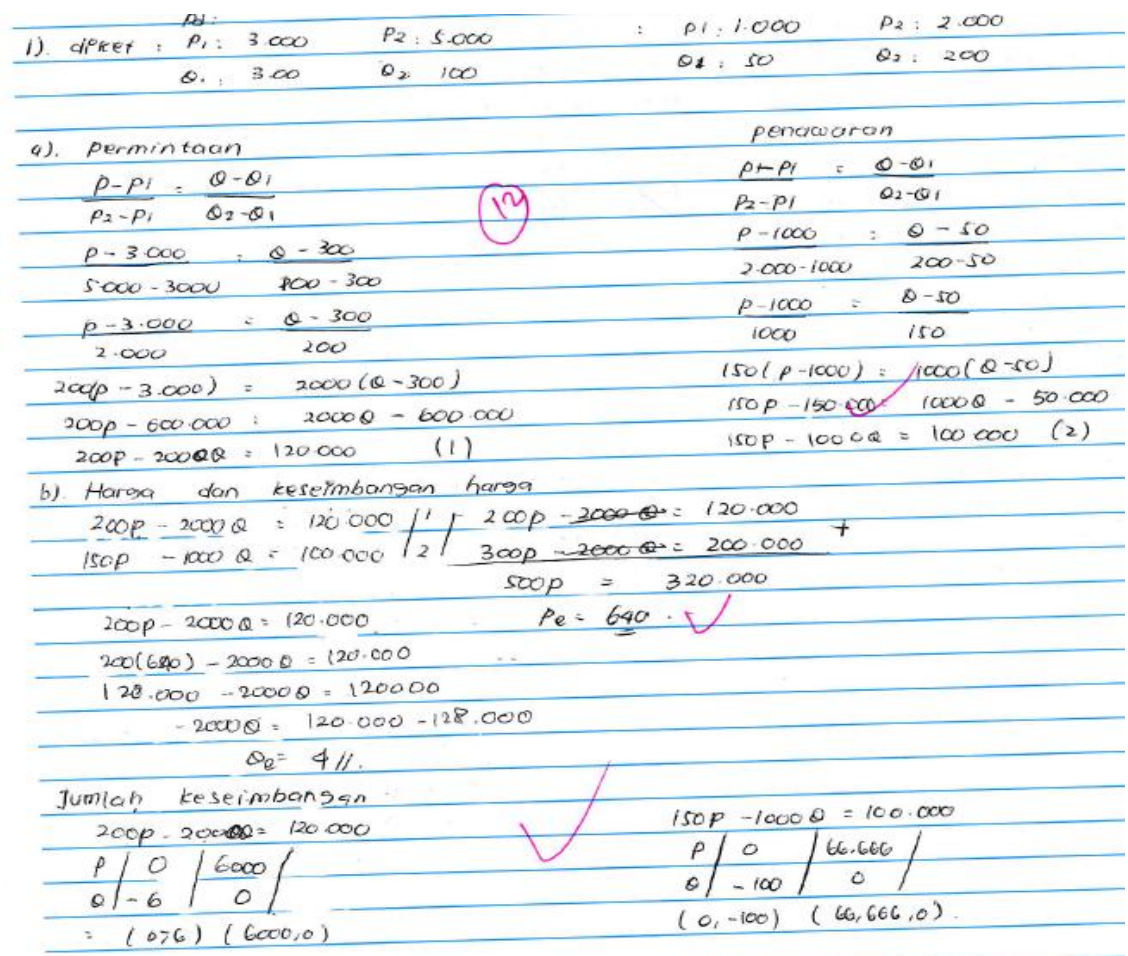

Gambar 3. Kesalahan Dalam Strategi Penyelesaian Masalah

Gambar 3 menunjukkan bahwa mahasiswa/i melakukan kesalahan dalam strategi penyelesaian masalah. Kesalahan mahasiswa pada strategi penyelesaian menghitung (tidak ada tanda minus).

Kasus Break Event Point

Pada kasus Break Event Point, terdapat berbagai kesalahan mahasiswa/i dalam memecahkan masalah sebagai berikut:

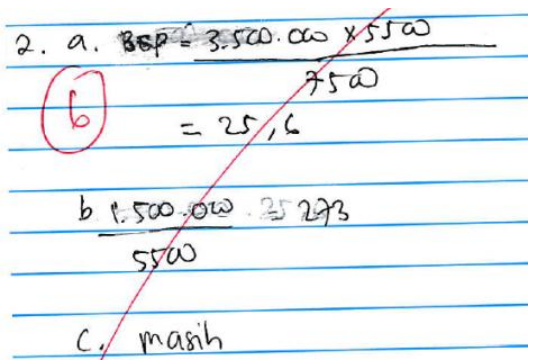

Gambar 4. Kesalahan Ketidakpahaman Konsep Break Event Point

Gambar 4 menunjukkan bahwa mahasiswa/i tidak memahami konsep break event point serta tidak dapat menerjemahkan Bahasa kasus ke dalam simbol matematika. Mahasiswa tidak memiliki gambaran apa yang diketahui dan apa yang yang ditanyakan, akibatnya 
dalam menyelesaikan kasus break event point tidak memiliki arah bagaimana memecahkan kasus tersebut.

(2) $\begin{aligned} F C & =3.500 .000 \quad(10) \\ V & =5.500 \\ P & =7.500 \\ \text { Dit } & =\text { Break Event Point ? } \\ T R & =P . Q \text { imaka } \\ Q & \left.=\frac{F C}{P . X}\right)_{Q}=\frac{3.500 \cdot 000}{7.500 .5500} \\ & =\frac{14}{165}=0,1 \\ T R & =P . Q \\ & =7500.0,1 \\ & =750\end{aligned}$

Gambar 5. Kesalahan Pembuatan Fungsi

Gambar 5 menunjukkan bahwa mahasiswa/i sudah mampu menerjemahkan bahasa kasus ke dalam simbol matematika namun belum mampu menentukan atau membuat fungsi biaya total dan fungsi penerimaan total dengan baik, serta penulisan rumus yang tidak tepat.

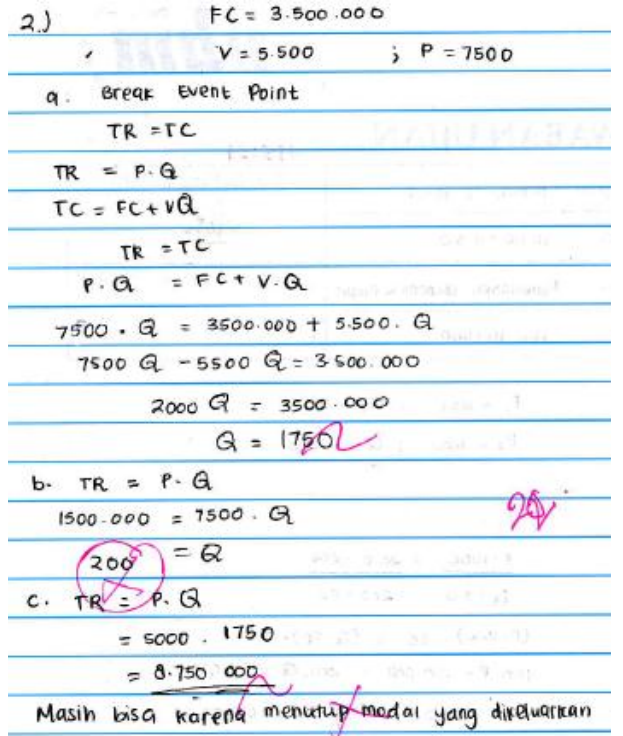

Gambar 6. Kesalahan Strategi

Perhitungan Menentukan Fungsi TR

Gambar 6 menunjukkan bahwa mahasiswa/i mampu menstransformasikan bahasa kasus ke dalam simbol matematika, mahasiswa/i mampu menentukan fungsi biaya total dan fungsi penerimaan total dengan baik, mahasiswa/i mampu menentukan strategi perumusan dengan baik. Kesalahan mahasiswa/i terletak pada strategi perhitungan menentukan fungsi TR. Kasus Program Linier

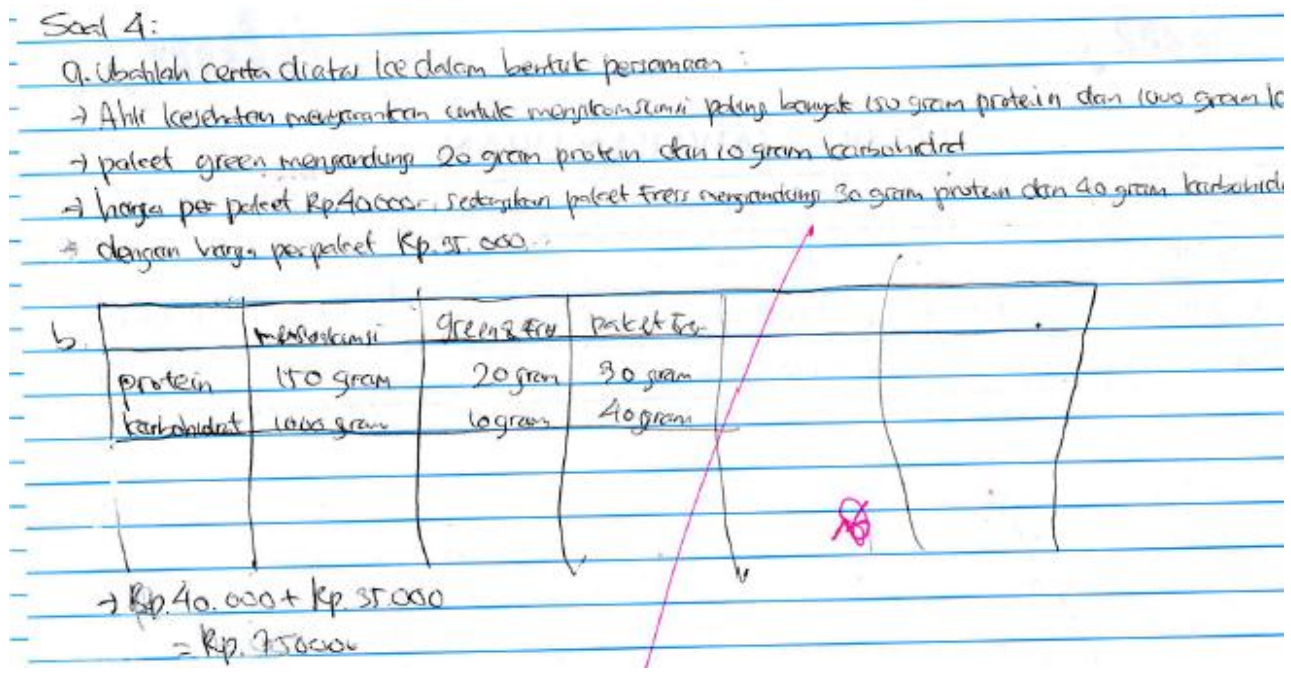


Gambar 7. Kesalahan Penilisan Fungsi Tujuan Dan Kendala

Gambar 7 menunjukkan bahwa mahasiswa/i sudah dapat menstransformasikan bahasa kasus ke model matematika fungsi kendala namun tidak mampu mengubahnya ke dalam bentuk fungsi. Mahasiswa/i tidak dapat menuliskan fungsi tujuan dan fungsi kendala.

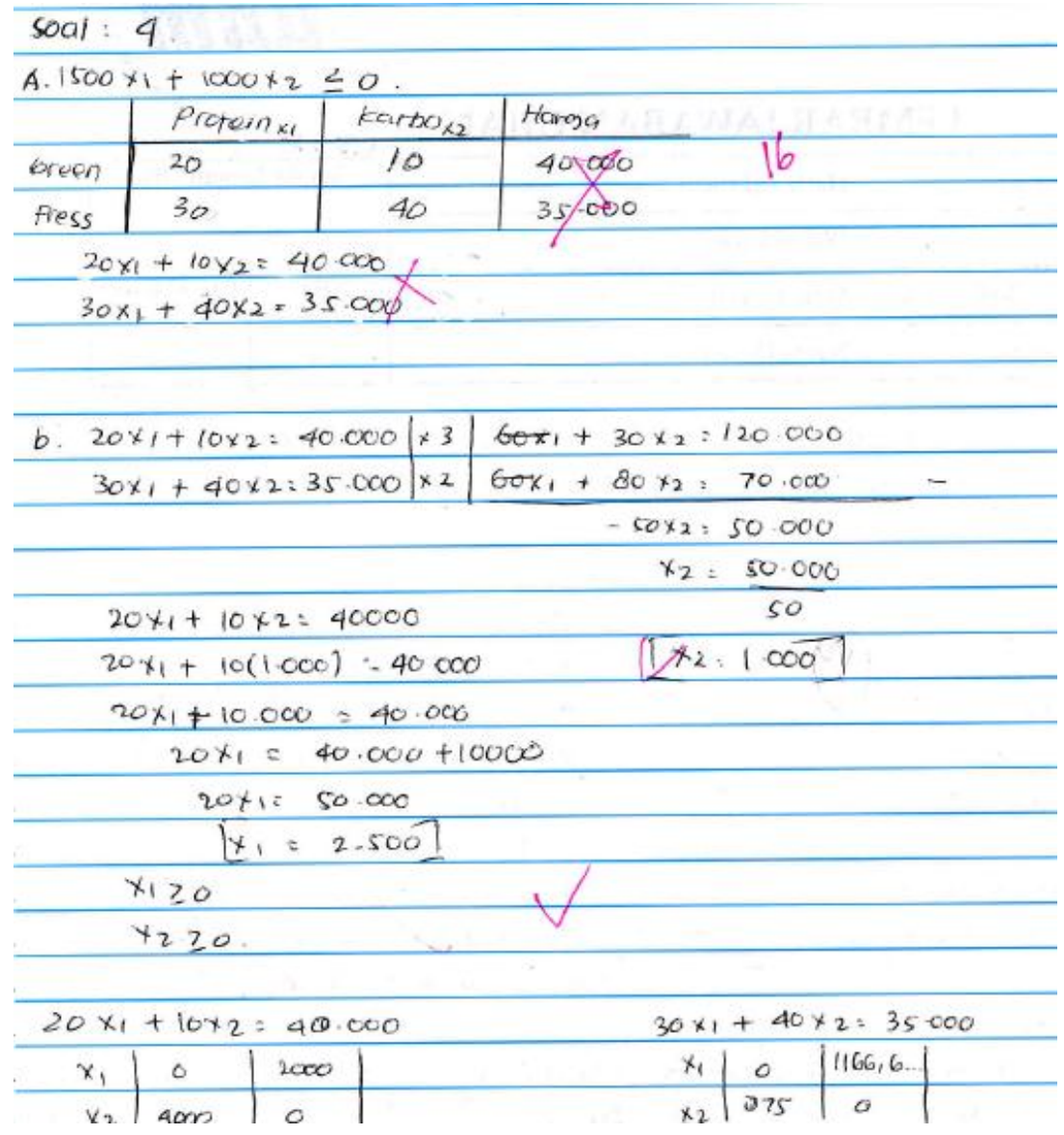

Gambar 8. Kesalahan Penempatan Fungsi Tujuan dan Fungsi Kendala

Gambar 8 menunjukan bahwa mahasiswa/i dapat menstranformasikan bahasa kasus ke dalam model matematika. Mahasiswa kurang memahami konsep program linier karena belum dapat membuat fungsi kendala secara benar dan fungsi tujuan. Kesalahan yang dilakukan adalah penempatan nilai fungsi tujuan pada fungsi kendala. 


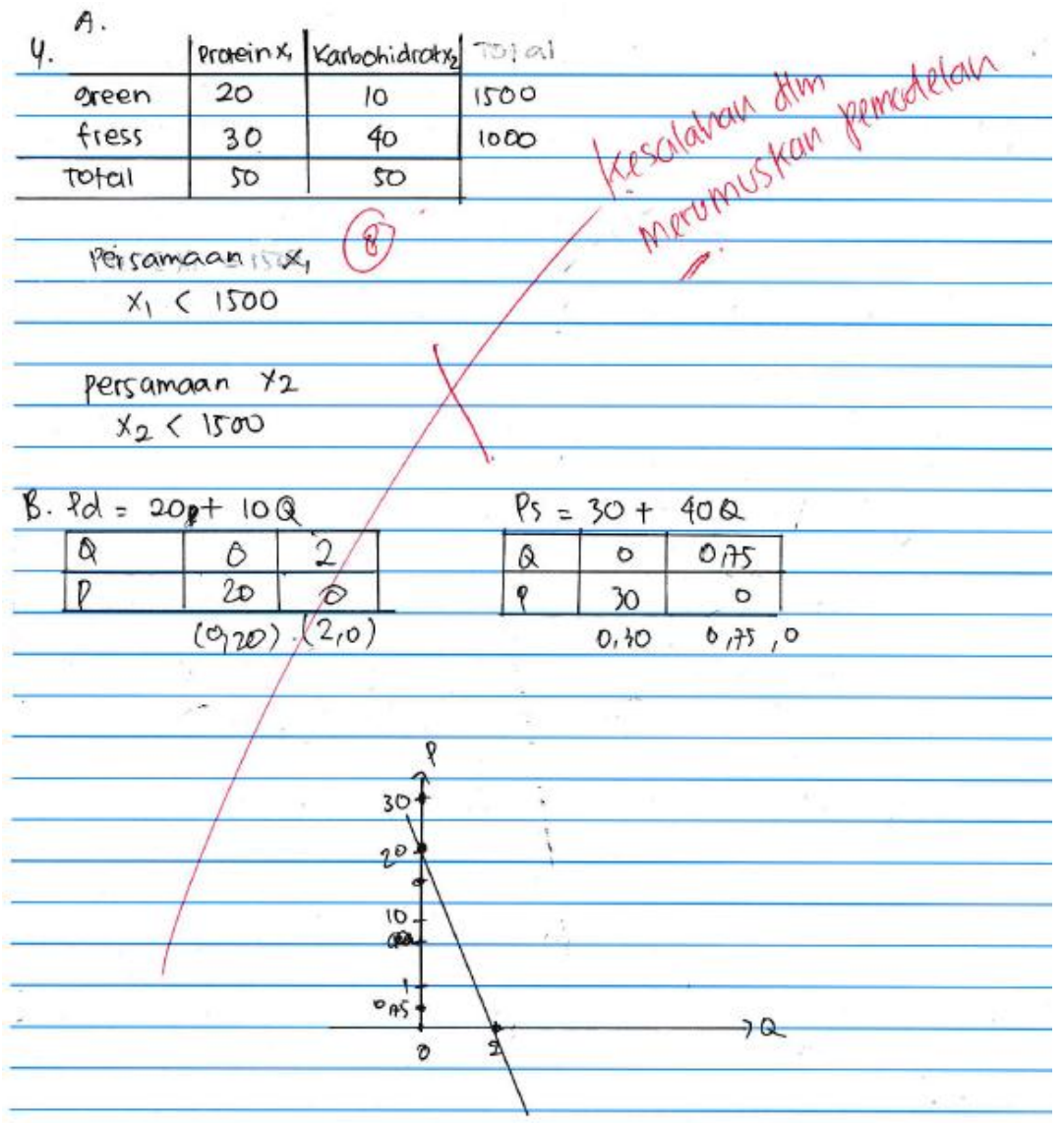

Gambar 9. Kesalahn Perumusan Pemodelan

Gambar 9 menunjukan bahwa mahasiswa/i mampu menggunakan strategi tranformasi bahasa kasus ke dalam model matematika namun belum dapat mengubah ke fungsi matematika pada saat menentuan fungsi kendala dan fungsi tujuan.

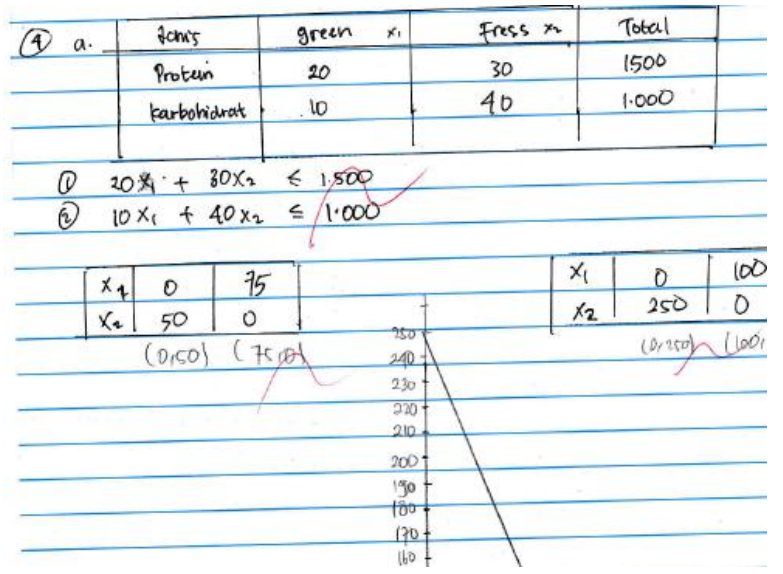

Gambar 10. Kesalahan Fungsi Tujuan

Gambar 10 menunjukan bahwa mahasiswa/i dapat menstranformasikan bahasa kasus ke dalam model matematika. Mahasiswa dapat menentukan fungsi kendala namum tidak dapat menentukan fungsi tujuan. 


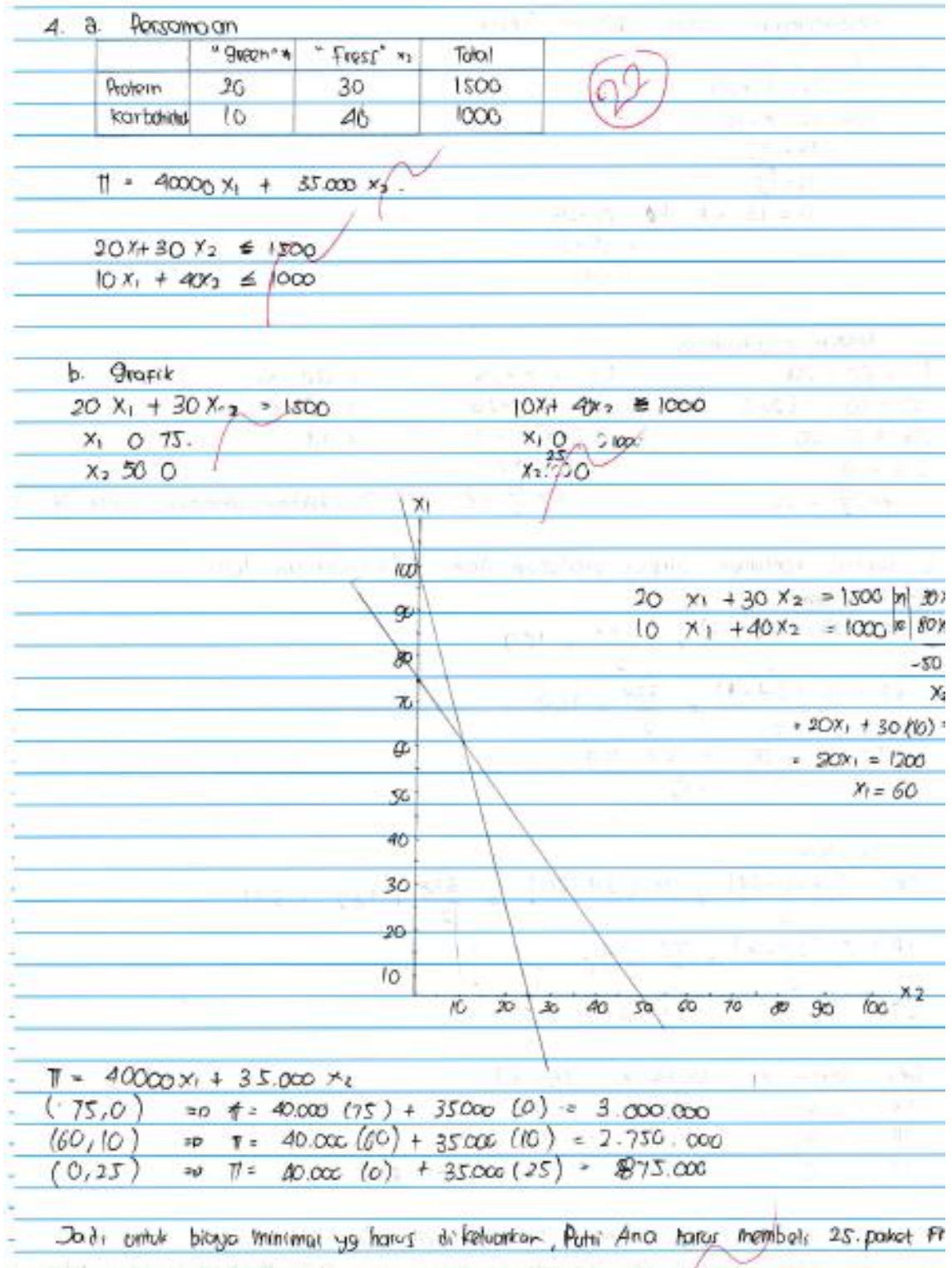

Gambar 11. Kesalahan Membuat Nilai Kritis

Gambar 11 menunjukan bahwa mahasiswa/i dapat menstranformasikan bahasa kasus ke dalam model matematika. Mahasiswa sudah memahami konsep program linier dalam menentukan fungsi kendala dan fungsi tujuan. Kesalahan yang dilakukan mahasiswa tersebut adalah dalam membuat nilai kritis dengan menggunakan metode grafik karena mahasiswa/i belum menguasi strategi menggambar grafik. 


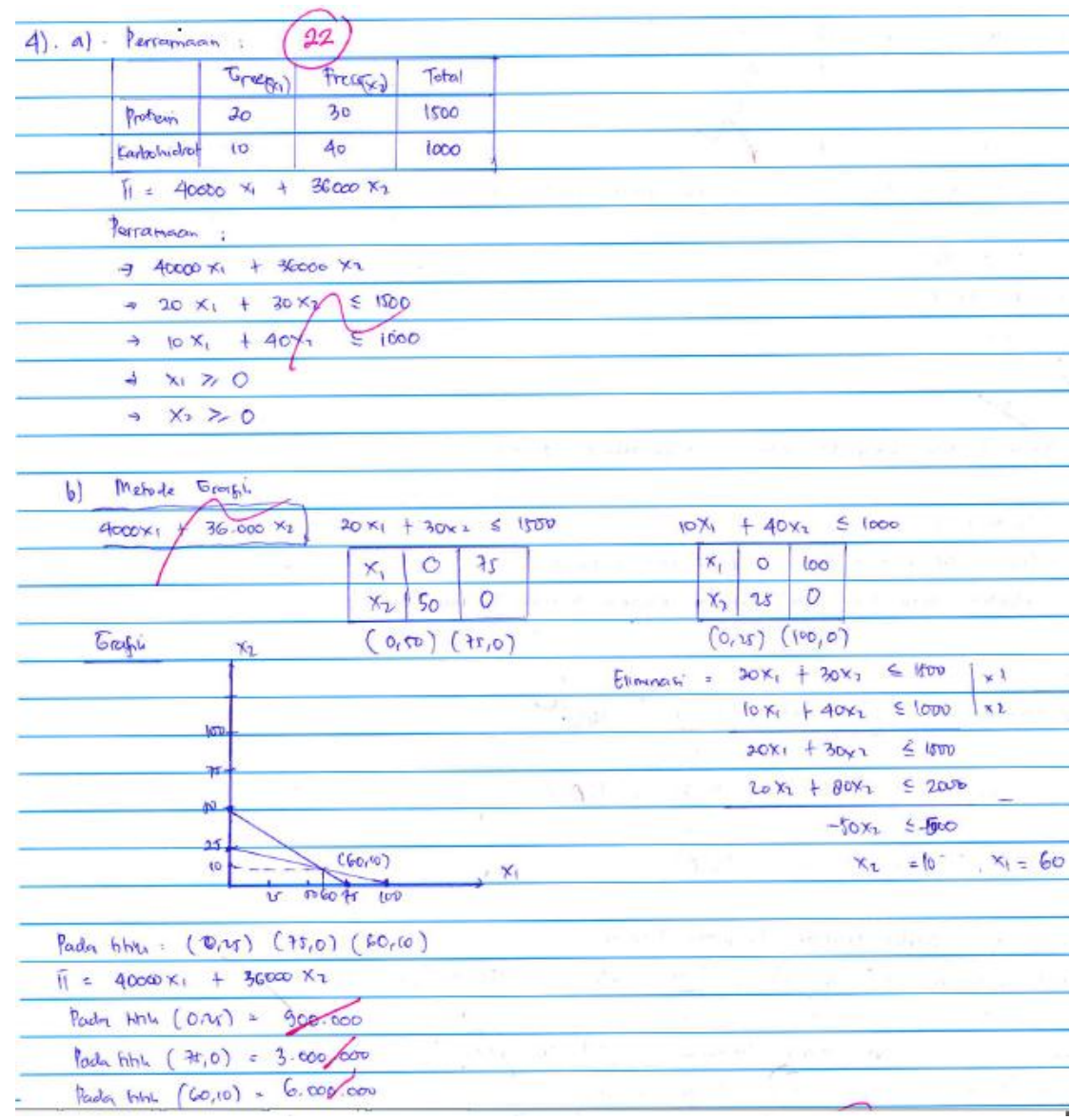

Gambar 12. Kesalahan Penentuan Nilai Optimum

Gambar 12 menunjukan bahwa mahasiswa/i dapat menstranformasikan bahasa kasus ke dalam model matematika. Mahasiswa sudah memahami konsep program linier dalam menentukan fungsi kendala dan fungsi tujuan. Mahasiswa/i sudah mampu menentukan strategi mementukan nilai kritis pada program linier dengan metode grafik. Kesalahan mahasiswa/i tersebut terletak pada hasil akhir penentuan nilai optimum karena ada kesalahan dalam menghitung.

Penyebab mahasiswa/i melakukan kesalahan dalam memecahkan kasus equilibrium, break event point dan Analisis ... (Herlina) program linear secara umum sebagai berikut:

1. Mahasiswa belum memahami bahasa kasus sehingga mahasiswa tidak dapat menstranformasikan bahasa kasus ke dalam simbol matematika. Penyebab terjadinya kesalahan ini sebagai berikut:

1) Mahasiswa belum belajar maksimal

2) Mahasiswa malas mengerjakan kasus berlogika

3) Mahasiswa sedikit mengetahui bagaimana membuat fungsi dari bahasa kasus

4) Kurang percaya diri dalam menuliskan fungsi matematikanya 
2. Mahasiswa melakukan kesalahan dalam menuliskan dalil matematika atau kesalahan dalam strategi perumusan sehingga mahasiswa/i mengalami kesulitan dalam analisis lebih lanjut. Penyebab terjadinya kesalahan sebagai berikut:

1) Mahasiswa salah memilih rumus

2) Mahasiswa melakukan kesalahan dalam penulisan rumus

3) Mahasiswa mengalami kecemasan sehingga nge-blank.

4) Mahasiswa belum paham dengan rumus
3. Mahasiswa/i melakukan kesalahan dalam strategi operasi hitung seperti penjumlahan, pengurangan, perkalian dan pembagian, serta konsep pindah ruas. Penyebab terjadinya kesalahan sebagai berikut:

1) Kurang teliti dalam mengerjakan operasi hitung

2) Konsep dasar matematika masih lemah

Berikut alasan-alasan mahasiswa tidak dapat mengerjakan kasus equlibrium, break event point dan program linier.

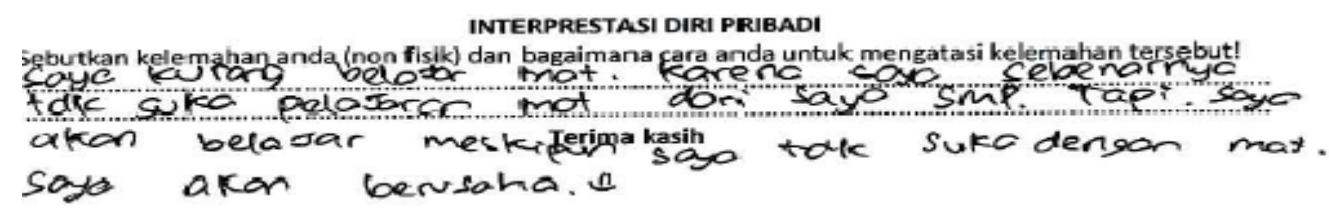

INTERPRESTASI DIRI PRIBADI

Sebutkan kelemahan anda (non fisik) dan bagaimana cara anda untuk mengatasi kelemahan tersebut!

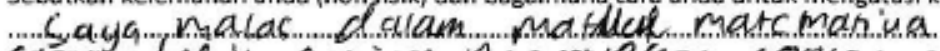

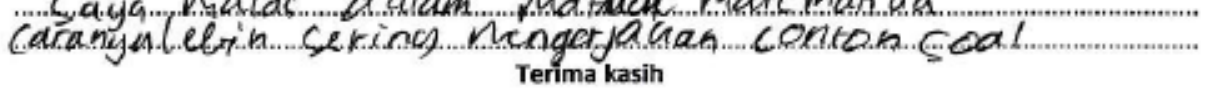

INTERPRESTASI DIRI PRIBADI

Sebutkan kelemahan anda (non fisik) dan bagaimana cara anda untuk mengatasi kelemahan tersebut!

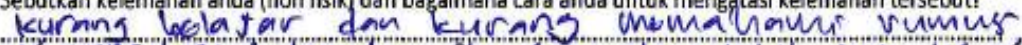

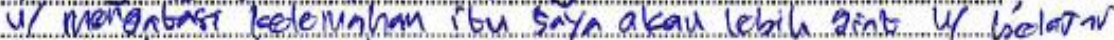
dacer memahami rupuus to. Terimakasih

INTERPRESTASI DIRI PRIBADI

Sebutkan kelemahan anda (non fisik) dan bagaimana cara anda untuk mengatasi kelemahan tersebut!

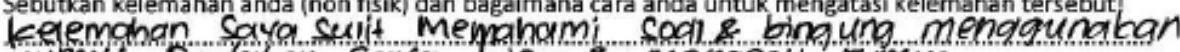
rumus padahal saya bisa \& mengert rimus

Terima kasih

Melinat contoh soal \& rumus.

INTERPRESTASI DIRI PRIBADI

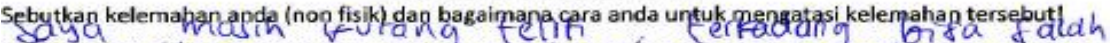
inenghiturg danterkadang \&uka membingungrean kalav mengerfafan, Terimakasih belum pernah dikervacan sebelum nya

INTERPRESTASI DIRI PRIBADI

Sebutkan kelemahan anda (non fisik) dan bagaimana cara anda untuk mengatasi kelemahan tersebut! curang fositi dim poca soal saloh loitung

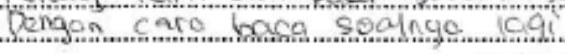

Terima kasih 


\section{INTERPRESTASI DIRI PRIBADI}

Sebutkan kelemahan anda (non fisik) dan bagaimana cara anda untuk mengatasi kelemahan tersebut! bicsanyg sciya kurong teliti dalam menghitung cara epngatasinya mulesi mambiasakcin utvic dovble check dakm inenghitung lesuatu

Terima kasih

\section{Gambar 13. Alasan Mahasiswa/i Mengenai Kesalahan}

Cara mengatasi pemecahan masalah pada kasus equilibrium, break event point dan program linear sebagai berikut:

1. Dosen memberikan latihan soal berupa kasus dan membahas penyelesaian secara bersama-sama serta memberitahukan titik-titik rawan kesalahan yang banyak dilakukan mahasiswa.

2. Dalam ujian tertutup, untuk mengurangi kesalahan penulisan rumus-rumus maka rumus-rumus perlu dicantumkan.

Selain cara diatas, dosen dihimbau untuk memberikan pendekatan berbeda dalam mengatasi kesulitan belajar mahasiswa/i seperti pendekatan membuat kelompok belajar sehingga mudah dipantau perkembangannya, memberikan motivasi belajar dan menerapkan model pembelajaran yang sesuai.

\section{Kesimpulan}

Berdasarkan analisis data kesalahan mahasiswa semester I Program Studi Manajemen Periode Genap 20152016 Universitas Bunda Mulia Jakarta Utara diperoleh simpulan sebagai berikut.
1. Kesalahan-kesalahan yang dilakukan mahasiswa dalam menyelesaikan kasus equlibrium, break event point \& program linier sebagai berikut:

a. Kasus Equlibrium

1) Kesalahan menerjemahkan bahasa, kesalahan pada saat menentukan apa yang diketahui dan apa yang tidak diketahui yaitu kesalahan menentukan harga dan kuantitas pada fungsi permintaan dan fungsi penawaran.

2) Kesalahan konsep, kesalahan dalam memberikan tanggapan konsep perumusan atau dalil matematika yaitu kesalahan dalam menentukan menuliskan rumus fungsi permintaan dan fungsi penawaran, kesalahan dalam menentukan syarat equlibrium.

3) Kesalahan strategi penyelesaian masalah, kesalahan dalam operasi hitung, kesalahan dalam pindah ruas, kesalahan dalam menentukan kesimpulan titik keseimbangan.

b. Kasus Break Event Point 
1) Kesalahan menerjemahkan bahasa, kesalahan pada saat menentukan apa yang diketahui dan apa yang tidak diketahui yaitu kesalahan menentukan biaya tetap, biaya variabel dan harga produk.

2) Kesalahan konsep, kesalahan dalam memberikan tanggapan konsep perumusan atau dalil matematika yaitu kesalahan menentukan menuliskan fungsi biaya total, fungsi penerimaan total dan syarat Break Event Point.

3) Kesalahan strategi penyelesaian masalah, kesalahan dalam operasi hitung, kesalahan dalam pindah ruas, kesalahan dalam menentukan kesimpulan titik impas atau break event point.

\section{c. Kasus Program Linier}

1) Kesalahan menerjemahkan bahasa, kesalahan pada saat menentukan apa yang diketahui dan apa yang tidak diketahui yaitu kesalahan menentukan manakah fungsi tujuan dan fungsi kendala.

2) Kesalahan konsep, kesalahan dalam memberikan tanggapan konsep perumusan atau dalil matematika yaitu kesalahan menentukan menuliskan fungsi tujuan dan fungsi kendala dan menentukan cara yang digunakan untuk menyelesaikan masalah.

3) Kesalahan strategi penyelesaian masalah, kesalahan dalam operasi hitung, menentukan daerah penyelesaian, menentukan titik-titik pembatas dan kesalahan menentukan kesimpulan nilai optimum sesuai dengan tujuan

2. Penyebab kesalahan mahasiswa dalam menyelesaikan kasus equlibrium, break event point, dan program linier sebagai berikut:

a. Penyebab kesalahan pada saat penerjemahan yaitu mahasiswa masih kurang paham apa yang ditanyakan.

b. Penyebab kesalahan pada saat tanggapan/konsep yaitu mahasiswa masih kurang paham apa yang menjadi tujuan soal sehingga mahasiswa masih bingung menentukan langkah apa yang akan dilakukan untuk menyelesaikan masalah tersebut.

c. Penyebab kesalahan pada saat strategi yaitu mahasiswa kurang teliti dalam melakukan oprasi hitung.

Selain sebab-sebab diatas, mahasiswa/i memiliki kendala dalam 
hal motivasi belajar, kecemasan mahasiswa pada saat ujian yang menyebabkan nge-blank mengakibatkan mahasiswa tidak fokus dalam menyelesaikan pemecahan masalah kasus equlibrium, break event point, dan program linier.

3. Cara mengatasi masalah mahasiswa/i dalam memecahkan kasus equilibrium, break event point dan program linear sebagai berikut:

a. Dosen memberikan latihan soal berupa kasus dan membahas penyelesaian secara bersama-sama serta memberitahukan titik-titik rawan kesalahan yang banyak dilakukan mahasiswa.

b. Dalam ujian tertutup, untuk mengurangi kesalahan penulisan rumus-rumus maka rumus-rumus perlu dicantumkan.

\section{Daftar Pustaka}

.Teori Pemecahan Masalah Polya dalam Pembelajaran Matematika.

https://masbied.files.wordpress.com /2011/05/modul-matematika-teoribelajar-polya.pdf (07-12-2015)

Joyner Mark. 2008. Simple.ology. Jakarta : PT Gramedia Pustaka Utama.

Kholid Noor. 2011. Analisa Kesalahan Mahasiswa/i Dalam Menyelesaikan soal Cerita Pada Mata Kuliah Program Linier (Studi pada mahasiswa/i Semester IV Program studi Pendidikan FKIP Universitas Muhamadiyah Surakarta). Prosiding Seminar Nasional Matematika Prodi Pendidikan Matematika. Universitas Muhammadiyah Surakarta.

Polya, George. ((1985). How To Solve It 2nd ed. New Jersey: Princeton University Press

Sanuasi anwar.2011. Metode Penelitian Bisnis. Jakarta. Salemba Empat. 